\title{
Optimising the attractiveness of winter oilseed rape fields as foraging habitat for the West Pannonian Great Bustard Otis tarda population during winter
}

\author{
RAINER RAAB, CLAUDIA SCHÜTZ, PÉTER SPAKOVSZKY, EIKE JULIUS and \\ CHRISTIAN H. SCHULZE
}

\begin{abstract}
Summary
Winter oilseed rape represents an important food source for Great Bustards. Great Bustard surveys during four consecutive winters (2005/2006-2008/2009) were used to identify characteristics of oilseed rape fields, which increase their attractiveness for the species in its West Pannonian wintering area. The study was conducted in study areas in Eastern Austria, around the AustrianSlovakian-Hungarian border and in the Hungarian Moson Plain. To test for effects of field size and isolation of fields from other rape fields, and the distance to the nearest paved road on occurrence and abundance of Great Bustards (maximum number of birds counted in individual rape fields per winter), we calculated generalized linear mixed models (GLMMs) including all three predictor variables as fixed effects and winter as random effect for each of the three study areas. Field size most strongly affected occurrence and abundance of Great Bustards. The availability of large ( $>15 \mathrm{ha}$ ) winter rape fields far from paved roads is recommended as a prime conservation measure to improve the quality of rape fields as foraging habitat for Great Bustards during the winter months (November-March).
\end{abstract}

\section{Introduction}

For resident bird populations at higher latitudes, winter conditions represent an important mortality factor (Graber and Graber 1979, Cawthorne and Marchant 1980). The availability of food can particularly influence the likelihood of birds dealing successfully with the often harsh environmental conditions during the winter months. The importance of an adequate food supply in winter has been demonstrated both empirically (Houston and Francis 1995) and experimentally through artificial food supplementation (Lahti et al. 1998).

In human-dominated landscapes crops such as winter oilseed rape can contribute a significant proportion of food used by birds during the winter months. For example, in Britain the introduction of oilseed rape Brassica napus provided an abundant winter food for the Common Woodpigeon Columba palumbus which as a consequence recovered from a population decline in the late 196os (Inglis et al. 1997). Oilseed rape fields are also an important foraging habitat in winter for Darkbellied Brent Geese Branta bernicla bernicla (McKay et al. 1996) and attract many other birds (Eyre et al. 2012).

Winter food supply for farmland birds such as game birds and insectivorous or granivorous passerines can be enhanced by cultivating seed-rich 'winter bird crops' (Henderson et al. 2004) and fodder brassica crops, by maintaining stubbles (Hancock and Wilson 2003) or by setting aside 
areas of arable farmland (Buckingham et al. 1999). These management actions are of particular importance since $58 \%$ of farmland and grassland bird species declined during 1990-2000 (BirdLife International 2004).

Great Bustards are mainly herbivorous, especially in the mid-winter period (December to March). During that time of year, faeces of Great Bustards in north-west Spain consisted almost entirely of green plant material and contained only a very small quantity of invertebrates and seeds (Lane et al. 1999). The importance of oilseed rape as food for Great Bustards has already been emphasised (Sterbetz 1980, Litzbarski et al. 1987, Kalmár and Faragó 2008) and its cultivation within traditional wintering areas has even been recommended as a conservation measure to decrease winter mortality (Nagy 2009). To optimise the value of rape fields as conservation tool for improving food availability for Great Bustards during winter, we studied how field parameters such as rape field size, isolation of fields from other rape cultivations and human disturbance affect their suitability as feeding habitat for West Pannonian Great Bustards. We expected that larger rape fields are preferred by Great Bustards. They do not just provide a larger amount of high-quality food but also may allow Great Bustards to escape human disturbance by movements within the rape field without the necessity of changing to another disturbance-free area by energy consuming flights. Consequently, minimising the need for movements between different rape fields by using large fields may decrease the importance of the distance between rape fields as predictor for rape field use. Human disturbance can also play an important role in habitat choice of Great Bustards (López-Jamar et al. 2011, Alonso et al. 2012, Burnside et al. 2014). Reducing escape flights induced by human disturbance may be particularly important during winter when energy loss has to be minimised. Therefore, we expect that a decreasing distance of rape fields to paved roads, used as proxy for human disturbance, will negatively affect the occurrence of Great Bustards.

\section{Methods}

\section{Study areas}

The study was conducted in a total of three areas which have been regularly used as winter habitat by the West Pannonian population of Great Bustards for at least 15 years. One was situated in the Westliches Weinviertel Special Protection Area (SPA) (WW; 1,560 ha) in Eastern Austria, the second one in the three SPAs - Parndorfer Platte - Heideboden, Sysl'ovské polia and Mosoni-sík ( $\mathrm{PH} ; 3,88 \mathrm{o}$ ha) on the Austrian-Slovakian-Hungarian border and the third one in the southern part of the Mosoni-sík SPA (MS; 3,004 ha) on the Moson Plain in Hungary (Figure 1).

The study areas are located in a mainly flat or gently undulating open landscape and are largely free of vertical structures such as trees or hedges, a landscape structure preferred by Great Bustards (Collar 1996, Osborne et al. 2001). All three study areas lack any natural grassland and mainly consist of arable land and are cultivated for the most part with winter and spring cereals, maize and various root crops. There is intensive cultivation, although agrienvironmental schemes are initiated to support the requirements of Great Bustards. Associated non-obligatory measures available to farmers due to the EAFRD (European Agriculture Fund for Rural Development) ensured that cultures of winter oilseed rape, lucerne and set-aside land cover a relatively large area of the study region. Winter rape covered on average $( \pm S D)$ $351.86( \pm 209.02)$ ha per winter at MS, $185.11( \pm 39.57)$ ha at PH and $137.80( \pm 35.51)$ ha at WW. The data on habitat cover were gathered through ground surveys on the basis of digital cadastre maps (1:1,000).

\section{Great Bustard counts}

Field work was conducted in the winters 2005/2006, 2006/2007, 2007/2008 and 2008/2009. During the four winters, all study areas were surveyed for Great Bustards from mid-November 


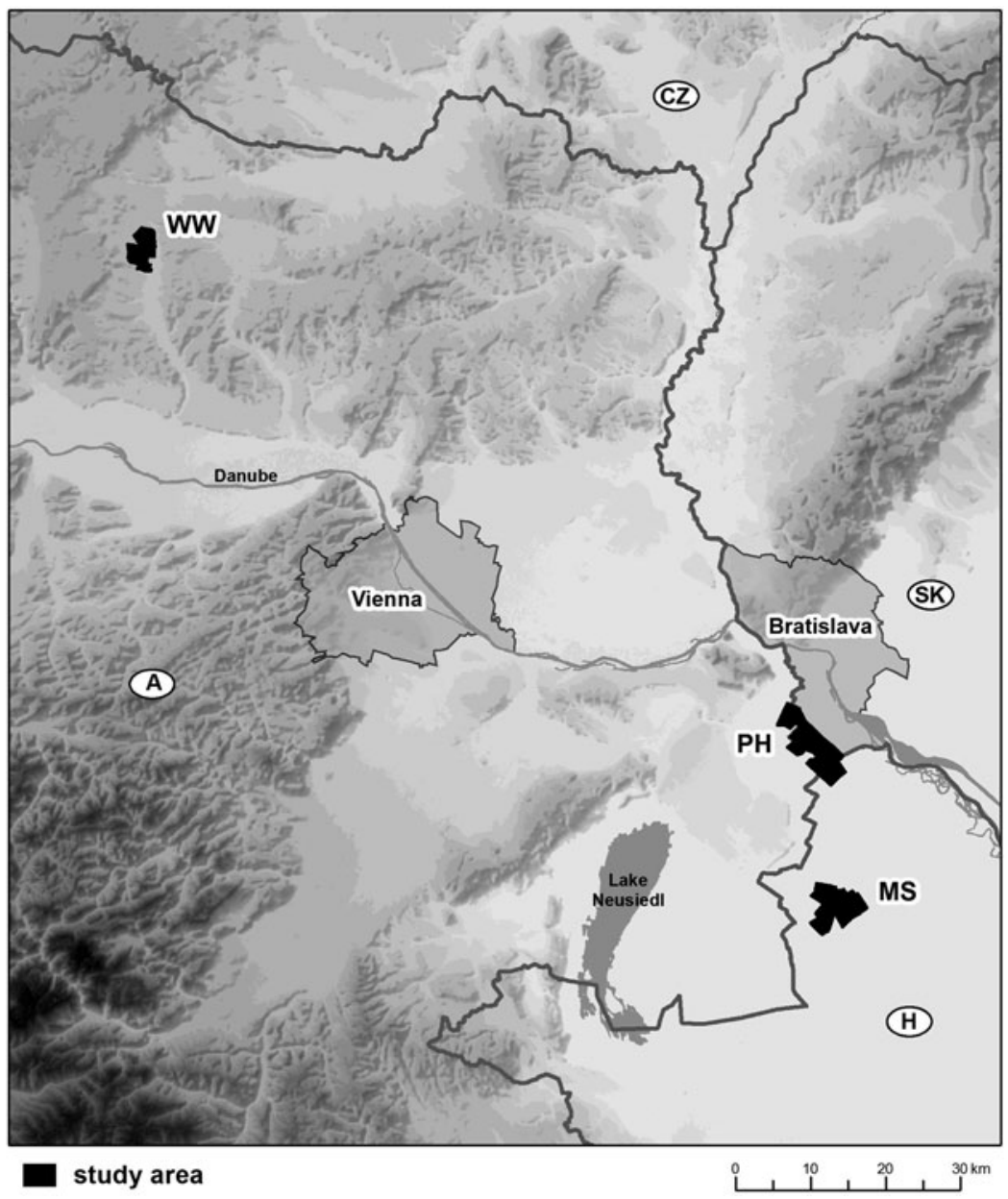

Figure 1. Map indicating the three study areas where Great Bustard surveys were conducted: MS - Mosoni-sík (Western Hungary); WW - Westliches Weinviertel (Eastern Austria); PH Parndorfer Platte-Heideboden (Eastern Austria), Sysl'ovské polia (Western Slovakia) and Mosoni-sík (Western Hungary).

until mid-March. MS was visited on a total of 68 days (20, 16, 19 and 13 days in the winters 2005/2006, 2006/2007, 2007/2008 and 2008/2009, respectively), PH on 55 days (18, 13, 10 and 14 days) and WW on 35 days ( $13,7,8$ and 7 days). Survey duration was approximately $3 \cdot 5,5.5$ and 3 hours per visit at MS, PH and WW, respectively, reflecting size differences of the study areas. During each visit the total study area was surveyed for birds. Locations of all encountered single individuals and flocks were immediately marked in the field on topographical (1:12,500) maps and, when observed in a rape field, assigned to an identified rape field. If more than one survey round was conducted per day, only the one with the higher total number of recorded Great Bustards was considered. When birds were observed changing their location during a survey round, only the first observation was considered for further analyses. Also if size and composition (e.g. sex and/or age ratio of individuals) of a flock was similar to a flock observed earlier that day and the latter flock could not be rediscovered again at its former location, the second observation was rated as a double count and was not considered in further analyses. 


\section{Winter rape fields and paved roads}

The two winter rape field parameters, size and isolation from other rape fields, were measured by ArcMap 9.I (ESRI) for all four winters. Field isolation was quantified as the median distance to the four nearest rape fields. Distances between fields were measured as the minimum distances between field margins. As a substitute for human disturbance, we measured the minimum distance between the field margin and the nearest paved road with ArcMap 9.I.

\section{Data analysis}

To assess effects of field size (log $\mathrm{x}$ transformed), field isolation ( $\sqrt{ } \mathrm{x}$ transformed) and distance from the field margin to the nearest paved road $(\sqrt{ } \mathrm{x}$ transformed) on the occurrence (incidence data: presence/absence) of Great Bustards in rape fields, Generalized Linear Mixed Models (GLMMs) with binomial error distribution and logit-link function were calculated. Winter was fitted as random factor. Due to differences in Great Bustard numbers in the three study areas, GLMMs were calculated separately for all three areas. GLMMs with winter fitted as random factor were also used to detect effects of field size, field isolation, and distance to nearest roads on the maximum number of Great Bustards counted in rape fields during individual winters. These GLMMs were calculated with a Poisson error structure and a log-link function, which is recommended for count data (e.g. Bolker et al. 2009). All GLMMs were calculated using standardised variables. All statistical analyses were conducted using STATISTICA version 7.I (StatSoft Inc. 2005).

\section{Results}

GLMMs (with winter as random effect) including the variables field size, field isolation and distance to nearest paved road indicate a significant effect of field size on Great Bustard occurrence for all three study areas (Table I). The probability of Great Bustard occurrence predicted by the GLMMs increased with rape field size in all three study areas (Figure 2). The rape field variables 'isolation' and 'distance to the next paved road' only affected the occurrence of Great Bustards in rape fields at the WW study area. However, both variables only weakly influenced the occurrence of Great Bustards as indicated by the small coefficients (Table 1 ).

Subsequently calculated univariate logistic regressions testing for effects of winter rape field size on the occurrence of Great Bustards also indicate a strongly increasing likelihood of occurrence with increasing field size for the study areas MS $\left(\chi^{2}=13.20, P<0.001\right)$ and $\mathrm{PH}\left(\chi^{2}=10.48\right.$, $P=0.001$; Figure 3). For WW only a weak positive effect of field size on the occurrence of Great

Table 1. Results of GLMMs (with the variable winter as random effect) testing for effects of field size, field isolation and distance from field margin to the next paved road on the occurrence of Great Bustards in winter rape fields for each of the three study areas. Significant effects are indicated in bold.

\begin{tabular}{llrlrrrr}
\hline Study area & Model term & \multicolumn{1}{l}{ F } & $P$ & Coefficient & SE & \multicolumn{2}{l}{$95 \%$ CI } \\
\cline { 4 - 7 } & & & & & & & \multicolumn{2}{l}{ Lower } & Upper \\
\hline MS & Field size & $\mathbf{8 . 8 9}$ & $\mathbf{0 . 0 0 4}$ & $\mathbf{1 . 0 2}$ & $\mathbf{0 . 3 4}$ & $\mathbf{0 . 3 3 5}$ & $\mathbf{1 . 7 1 2}$ \\
& Field isolation & 3.03 & 0.088 & 0.06 & 0.04 & -0.009 & 0.134 \\
& Distance to next road & 3.92 & 0.053 & 0.05 & 0.03 & -0.001 & 0.102 \\
PH & Field size & $\mathbf{5 . 9 8}$ & $\mathbf{0 . 0 1 6}$ & $\mathbf{0 . 5 1}$ & $\mathbf{0 . 2 1}$ & $\mathbf{0 . 0 9 7}$ & $\mathbf{0 . 9 1 5}$ \\
& Field isolation & $\mathbf{1 . 4 9}$ & 0.224 & 0.03 & 0.22 & -0.020 & 0.084 \\
& Distance to next road & $\mathbf{1 . 8 3}$ & 0.179 & -0.03 & 0.02 & -0.069 & 0.013 \\
WW & Field size & $\mathbf{8 . 2 7}$ & $\mathbf{0 . 0 0 4}$ & $\mathbf{0 . 8 6}$ & $\mathbf{0 . 3 0}$ & $\mathbf{0 . 2 7 1}$ & $\mathbf{1 . 4 4 9}$ \\
& Field isolation & $\mathbf{9 . 4 8}$ & $\mathbf{0 . 0 0 2}$ & $\mathbf{0 . 1 1}$ & $\mathbf{0 . 0 3}$ & $\mathbf{0 . 0 3 8}$ & $\mathbf{0 . 1 7 2}$ \\
& Distance to next road & $\mathbf{1 1 . 3 4}$ & $\mathbf{0 . 0 0 1}$ & $\mathbf{0 . 1 1}$ & $\mathbf{0 . 0 3}$ & $\mathbf{0 . 0 4 7}$ & $\mathbf{0 . 1 7 8}$ \\
\hline
\end{tabular}




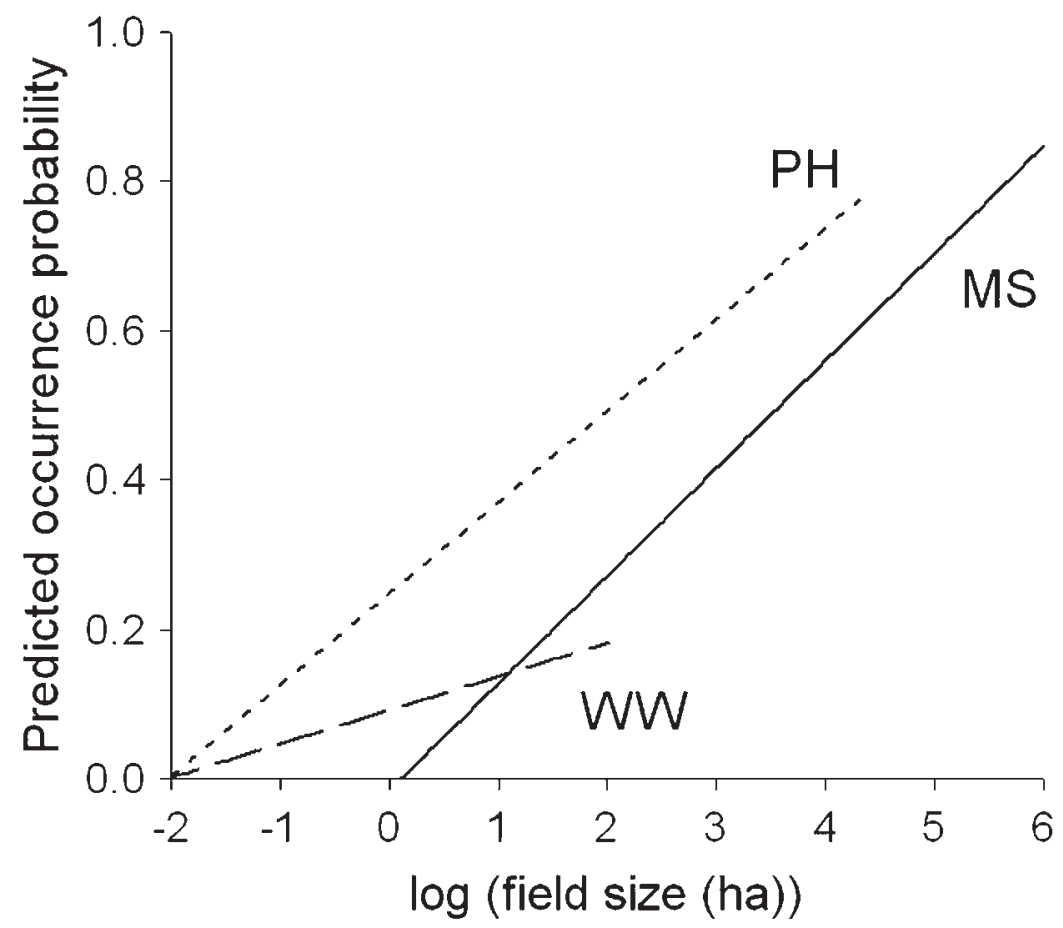

Figure 2. The relationship between probability of Great Bustard occurrence in winter rape fields and field size predicted by GLMMs including the variables field size, field isolation and distance of fields to the next paved road. Visualized are resulting linear regression curves for all three study areas: MS - Mosoni-sík; WW - Westliches Weinviertel; PH - Parndorfer Platte-Heideboden, Sysl'ovské polia and Mosoni-sík.

Bustards was found $\left(\chi^{2}=3.94, P=0.047\right)$, perhaps because average size of rape fields was smaller at WW than at MS and PH in all winters (Figure $\mathrm{S}_{1}$ in the online supplementary material). Both the logistic regression curves for MS and PH indicate a 50\% likelihood of Great Bustard occurrence in winter rape fields for a field size of c.15 ha (Figure 3).

GLMMs testing for effects of all three rape field variables on the maximum number of Great Bustards counted per winter in individual rape fields again indicate a significant effect of field size in the three study areas. Although field isolation at MS and WW and distance to the nearest paved road at all three study areas also proved to significantly influence Great Bustard numbers in rape fields, their comparably small coefficients provide evidence that they were only of minor importance for predicting numbers (Table 2). An increase in isolation of rape fields and distance to paved roads both appeared to positively affect the number of Great Bustards at MS and WW. In contradiction, the distance to the nearest paved road was negatively related to Great Bustard numbers at $\mathrm{PH}$.

\section{Discussion}

Farming activities can be the major determinant of food abundance and availability for wintering birds (Tucker 1992, Gill et al. 1996). As a consequence, farming can affect habitat use of birds and even contribute to an increase in bird populations (Inglis et al. 1997, Guzmán et al. 1999, Gauthier et al. 2005, López-Jamar et al. 2011, Martín et al. 2012). Especially for Great Bustards, 


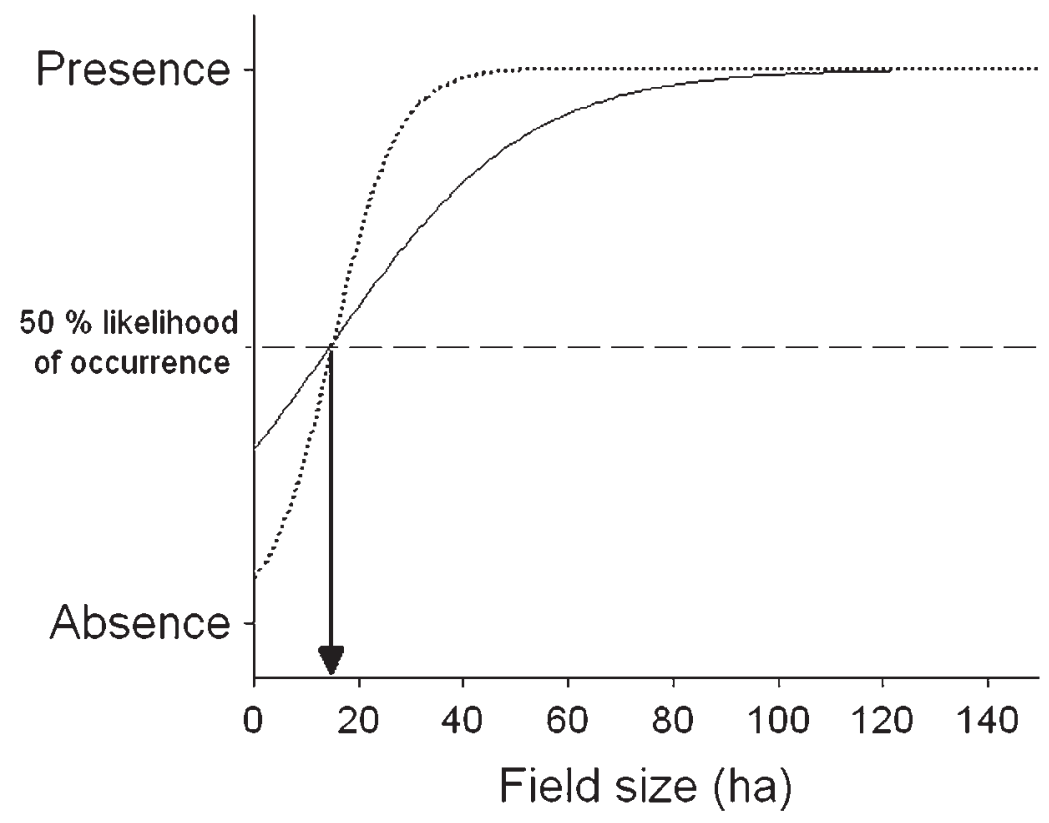

Figure 3. Likelihood of Great Bustard occurrence in winter rape fields in relation to field size, described by logistic regressions calculated separately for the two study areas MS (solid line) and $\mathrm{PH}$ (dotted line). The arrow indicates the field size at which the likelihood of Great Bustard occurrence is $50 \%$.

areas dominated by agriculture provide very important feeding habitats. Perhaps the nutritional value of the rape leaves and the fact that rape is less often covered by snow than other food sources like winter cereal sowings (Inglis et al. 1997) makes rape a profitable food resource for Great Bustards during the winter months.

In our study region, the size of winter rape fields appeared to have a significant effect on their importance as feeding habitat for Great Bustards. Both Great Bustard numbers and the likelihood of occurrence increased with increasing field size. In Pink-footed Geese Anser brachyrhynchus

Table 2. Results of GLMMs (with the variable winter as random effect) testing for effects of field size, field isolation and distance from field margin to the next paved road on the maximum number of Great Bustards in winter rape fields recorded per year, separately calculated for the three study areas. Significant effects are indicated in bold.

\begin{tabular}{|c|c|c|c|c|c|c|c|}
\hline \multirow[t]{2}{*}{ Study area } & \multirow[t]{2}{*}{ Model term } & \multirow[t]{2}{*}{$F$} & \multirow[t]{2}{*}{$P$} & \multirow[t]{2}{*}{ Coefficient } & \multirow[t]{2}{*}{ SE } & \multicolumn{2}{|l|}{$95 \% \mathrm{CI}$} \\
\hline & & & & & & Lower & Upper \\
\hline \multirow[t]{3}{*}{ MS } & Field size & $354 \cdot 72$ & $<0.001$ & 0.94 & 0.05 & 0.844 & 1.045 \\
\hline & Field isolation & $83 \cdot 72$ & $<0.001$ & 0.04 & 0.01 & 0.035 & 0.054 \\
\hline & Distance to road & 145.43 & $<0.001$ & 0.05 & $<0.01$ & 0.038 & 0.053 \\
\hline \multirow[t]{3}{*}{ PH } & Field size & 938.34 & $<0.001$ & 0.61 & 0.02 & 0.580 & 0.660 \\
\hline & Field isolation & 2.10 & 0.150 & -0.01 & $<0.01$ & -0.010 & 0.002 \\
\hline & Distance to road & 168.04 & $<0.001$ & -0.03 & $<0.01$ & -0.029 & -0.021 \\
\hline \multirow[t]{3}{*}{ WW } & Field size & 190.04 & $<0.001$ & 0.65 & 0.05 & 0.559 & 0.745 \\
\hline & Field isolation & 420.76 & $<0.001$ & 0.10 & 0.01 & 0.089 & 0.108 \\
\hline & Distance to road & 290.43 & $<0.001$ & 0.09 & 0.01 & 0.075 & 0.095 \\
\hline
\end{tabular}


field size was also shown to be an important predictor variable for field use and even seemed to have a greater effect than the biomass available on particular fields (Gill et al. 1996). Furthermore, fields under 6 ha in size and close to roads were often completely avoided by the geese (Gill et al. 1996). The size of rape fields which attracted Great Bustards with a likelihood of $50 \%$ was remarkably similar at MS and PH. At both study sites the value was approximately 15 ha. This may explain the weak explanatory power of field size for Great Bustard occurrence in individual rape fields at WW, where all rape fields were below a size of 9 ha.

Although it was stated earlier that fully grown Great Bustards have hardly any natural predators (Glutz von Blotzheim et al. 1994), a more recent study on mortality causes of juvenile and immature birds in Spain classified red foxes Vulpes vulpes and feral dogs as potentially frequent predators (Martín et al. 2007). However, so far feral dogs have not been recorded as predators of juvenile or adult Great Bustards in our study region. Eagles represent not only an important source of disturbance (Eisenberg et al. 2002, Sastre et al. 2009, pers. obs.) they can even kill Great Bustards. For example, in Germany 50 birds (but predominantly chicks and juveniles) were killed by White-tailed Eagles Haliaaetus albicilla since 2000 (T. Langgemach pers. comm.). Great Bustards are particularly sensitive to human disturbance (Sastre et al. 2009, pers. obs.) and respond to humans with an escape flight already at distances of several hundred metres (pers. obs.). Therefore, they may prefer larger fields because these should provide more potential refuge areas (i.e. parts of the field opposite to a source of disturbance) which can be reached by walking, thereby preventing large-scale flight movements to reach other (perhaps less profitable) feeding habitats. A higher frequency of flight movements can have a severe negative impact on the birds' energy budget, especially in mid- or late winter when hours of daylight are limited, food resources have already been noticeably depleted and regrowth of plants is very low (Riddington et al. 1996). Great Bustards weigh up to $18 \mathrm{~kg}$ (Collar 1996) and feed during the winter months mainly on nutrient-poor green plant material (Lane et al. 1999, Rocha et al. 2005), which is difficult to digest (Begon et al. 1990). In such birds flight movements can represent particularly high energy expenditure. In addition, wintering Great Bustards mostly forage in flocks and smaller fields may not be attractive enough for a large number of birds. Indeed our data also indicate that the size of Great Bustard flocks feeding in winter rape fields increases with field size.

Sources of disturbance associated with roads or paths like cars, walkers, motorcyclists or cyclists are identified as "high-risk threatening factors" by Great Bustards and usually cause a flight response (Sastre et al. 2009). This may explain the weak positive effect of the minimal distance between field margins and paved roads on Great Bustard occurrence (at WW) and recorded maximum numbers (at MS and WW). Surprisingly, a very weak negative effect of the distance between field margin and the nearest paved road and the maximum number of counted Great Bustards was indicated by the GLMM calculated for PH. Weak positive effects of field isolation on occurrence and maximum counts of Great Bustards were found at WW and MS and WW, respectively. Perhaps, more isolated fields attract Great Bustards passing accidentally, independent of field size.

Providing a sufficient supply of winter oilseed rape during winter months should be a priority in habitat management of the West Pannonian Great Bustard population. Unfortunately, in the Austrian part of our study region winter rape fields are less profitable than cultivation of other annual crops. Therefore, the cultivation of winter rape in the near future can just be maintained by providing financial support to the farmers for special winter rape fields in the Great Bustard areas. Supporting winter grazing areas for Great Bustards by means of the Austrian Rural Development Program has already been realised within a LIFE-Nature project (LIFEo5 NAT/A/oooo77; http://www.grosstrappe.at) addressing the conservation of the West Pannonian Great Bustard population, and two further projects financed by the local government of Lower Austria and the European Commission (RD project $\mathrm{RU}_{5}-\mathrm{S}-428$ /oo12005; http://www.grosstrappe.at) and the local government of Burgenland (LPF project 5-NA1025/148-2009; http://www.grosstrappe.at). Furthermore, access to these winter grazing areas should be ensured during the whole winter. Removal of snow, which may become deep and 
crusty, is an important action to undertake (Nagy 2009), since a snow cover of only $5 \mathrm{~cm}$ covers all potential food plants of Great Bustards, which they then have to pull out of the snow using only their bills (Streich et al. 2006).

Our data indicate a clear preference for larger winter rape fields ( $>15$ ha) by Great Bustards. This observation has important implications for habitat management. The establishment of larger rape fields in traditional winter grazing areas can potentially attract Great Bustards to a predictable number of focal areas. Here, potential sources of disturbance can be more effectively controlled or reduced during the sensitive winter months, when food is generally limited. Also, rape fields should be established as far as possible from paved roads with high disturbance levels causing frequent escape flights, which increase energy expenditure and could additionally increase the risk of collision with man-made structures such as power lines (e.g. Alonso et al. 2005, Pinto et al. 2005). Such collisions can represent the main non-natural cause of mortality for adult Great Bustards (Martín et al. 2007, Raab et al. 2012), although they are able to adapt their flight behaviour (Raab et al. 2011). This risk should be reduced by establishing rape fields far from existing power lines to reduce the risk of collision (Nagy 2009). Our recommendations for improving the habitat management in the species' West Pannonian distribution range are relevant for the region's entire breeding population, which winters exclusively in these three areas (as indicated by the monthly winter counts; Raab et al. unpubl. data).

Winter food of West Pannonian Great Bustards certainly comprises a large fraction of oilseed rape. However, the composition of the diet of Great Bustards (Lane et al. 1999, Rocha et al. 2005) and their selection of foraging habitats underlies seasonal changes (Moreira et al. 2004) and varies geographically (Morales et al. 2006). At the same time wintering and breeding areas can spatially overlap to a large extent, as in the West Pannonian Great Bustard population. Therefore, supporting special winter grazing areas for Great Bustards during winter months should not be at the cost of other habitats that are important at other times of the year, like set-aside land during the breeding season (Rocha et al. 2013). So maintaining a mosaic of different habitat types is essential for satisfying the requirements of Great Bustards in agricultural landscapes throughout the whole year. Furthermore, the behavioural context has to be considered. Different land uses provide more choices for birds not only for feeding but also displaying, resting, preening etc. Therefore, we not only recommend maintaining large winter rape field cover but also other habitats such as fallows, a management measure also important for other farmland birds (Tucker 1992).

\section{Supplementary Material}

The supplementary materials for this article can be found at journals.cambridge.org/bci

\section{Acknowledgements}

We would like to give our special thanks to more than 450 farmers for providing part of their fields to support suitable winter grazing areas for Great Bustards by means of the Austrian Rural Development Program within the LIFE project LIFEo5 NAT/A/oooo77, the RD project RU5-S428/001-2005 and the LPF project 5-N-A1025/148-2009. For the most part field work took place within the two LIFE Projects "Crossborder Protection of the Great Bustard in Austria" (LIFEo5 NAT/A/oooo77, www.grosstrappe.at) and "Conservation of Otis tarda in Hungary" (LIFEo4 NAT/HU/oooıog, www.tuzok.hu). Most of the analyses were completed within the LIFE+ Project "Crossborder Protection of the Great Bustard in Austria - continuation" (LIFEog NAT/ AT/ooo225, www.grosstrappe.at). All three LIFE Projects are supported by the EU, many project partners and co-funders. Without this support the time-consuming work for the conservation of the entire West Pannonian Great Bustard population during recent years would not have been possible. Finally, we are grateful to Luc Lens, Dan Chamberlain, Kate Ashbrook, Al Dawes, Allan Goddard, Andrew Taylor, Tracé Williams and two anonymous reviewers for providing helpful comments, which significantly improved the manuscript. 


\section{References}

Alonso, J. C., Martín, C. A., Palacín, C., Martín, B. and Magaña, M. (2005) The Great Bustard Otis tarda in Andalusia, southern Spain: status, distribution and trends. Ardeola 52: 67-78.

Alonso, J. C., Álvarez-Martínez, J. M. and Palacín, C. (2012) Leks in ground-displaying birds: hotspots or safe places? Behav. Ecol. 23: 491-501.

Begon, M., Harper, J. L. and Townsend, C. R. (1990) Ecology - individuals, populations and communities. Oxford, UK: Blackwell Science.

BirdLife International (2004) Birds in Europe: population estimates, trends and conservation status. Cambridge, UK: BirdLife International.

Bolker, B. M., Brooks, M. E., Clark, C. J., Geange, S. W., Poulsen, J. R., Stevens, M. H. H. and White, J. S. (2009) Generalized linear mixed models: a practical guide for ecology and evolution. Trends Ecol. Evol. 24: 127-135.

Buckingham, D. L., Evans, A. D., Morris, A. J., Orsman, C. J. and Yaxley, R. (1999) Use of set-aside land in winter by declining farmland bird species in the UK. Bird Study 46 : 157-169.

Burnside, R. J., Végvari, Z., James, R., Konyhás, S., Kovács, G. and Székely, T. (2014) Human disturbance and conspecifics influence display site selection by Great Bustards Otis tarda. Bird Conserv. Internatn. 24: 32-44.

Cawthorne, R. A. and Marchant, J. H. (1980) The effects of the $1978 / 79$ winter on British bird populations. Bird Study 27: 163-172.

Collar, N. J. (1996) Family Otididae (Bustards). Pp 240-273 in J. del Hoyo, A. Elliott and J. Sargatal, eds. Handbook of the birds of the world. Vol. 3. Hoatzin to auks. Barcelona, Spain: Lynx Edicions.

Eisenberg, A., Ryslavy, T., Putze, M. and Langgemach, T. (2002) Ergebnisse der Telemetrie bei ausgewilderten Großtrappen (Otis tarda) in Brandenburg 1999-2002. Otis 10: 133-150.

Eyre, M. D., Hughes, M. and Leifert, C. (2012) Winter bird activity in fields on a split conventional/organic farm in northern England. Org. Agr. 2: 197-203.
Gauthier, G., Giroux, J.-F., Reed, A., Béchet, A. and Bélanger, L. (2005) Interactions between land use, habitat use, and population increase in Greater Snow Geese: what are the consequences for natural wetlands? Glob. Change Biol. 11: 856-868.

Gill, J. A., Watkinson, A. R. and Sutherland, W. J. (1996) The impact of sugar beet farming practice on wintering Pink-footed Goose Anser brachyrhynchus populations. Biol. Conserv. 76: 95-100.

Glutz von Blotzheim, U. N., Bauer, K. M. and Bezzel, E. (1994) Handbuch der Vögel Mitteleuropas, Band 5: Galliformes und Gruiformes. Wiesbaden, Germany: AulaVerlag.

Graber, J. W. and Graber, R. R. (1979) Severe winter weather and bird populations in southern Illionois. Wilson Bull. 91: 88-103.

Guzmán, J. M. S., García, A. S., Amado, C. C. and del Viejo, A. M. (1999) Influence of farming activities in the Iberian Peninsula on the winter habitat use of Common Crane (Grus grus) in areas of its traditional migratory routes. Agric. Ecosyst. Environ. 72: 207-214.

Hancock, M. H. and Wilson, J. D. (2003) Winter habitat associations of seed-eating passerines on Scottish farmland. Bird Study 50: 116-130.

Henderson, I. G., Vickery, J. A. and Carter, N. (2004) The use of winter bird crops by farmland birds in lowland England. Biol. Conserv. 118: 21-32.

Houston, C. S. and Francis, C. M. (1995) Survival of Great Horned Owls in relation to the Snowshoe Hare cycle. Auk 112: 44-59.

Inglis, I. R., Isaacson, A. J., Smith, G. C., Haynes, P. J. and Thearle, R. J. P. (1997) The effect on the Woodpigeon (Columba palumbus) of the introduction of oilseed rape into Britain. Agric. Ecosyst. Environ. 61: 113-121.

Kalmár, S. and Faragó, S (2008) A túzok védelme Magyarországon, Life Nature Project 20072008, évi monitoring jelentése. Hung. Small Game Bull. Suppl. 2008: 14-19.

Lahti, K., Orell, M., Rytkönen, S. and Koivula, K. (1998) Time and food dependence in Willow Tit winter survival. Ecology 79: 2904-2916. 
Lane, S. J., Alonso, J. C., Alonso, J. A. and Naveso, M. A. (1999) Seasonal changes in diet and diet selection of Great Bustards (Otis tarda) in north-west Spain. J. Zool. 247: 201-214.

Litzbarski, B., Litzbarski, H. and Petrick, S. (1987) Zur Ökologie und zum Schutz der Großtrappe (Otis tarda L.) im Bezirk Potsdam. Acta Ornithoecol. 1: 199-245.

López-Jamar, J., Casas, F., Díaz, M. and Morales, M. B. (2011) Local differences in habitat selection by Great Bustards Otis tarda in changing agricultural landscapes: implications for farmland bird conservation. Bird Conserv. Internatn. 21: 328-341.

Martín, C. A., Alonso, J. C., Alonso, J. A., Palacín, C., Magaña, M. and Martín, B. (2007) Sex-biased juvenile survival in a bird with extreme size dimorphism, the Great Bustard Otis tarda. J. Avian Biol. 38: 335-346.

Martín, C. A., Martínez, C., Bautista, L. M. and Martín, B. (2012) Population increase of the Great Bustard Otis tarda in its main distribution area in relation to changes in farming practices. Ardeola 59: 31-42.

McKay, H. V., Langton, S. D., Milsom, T. P. and Feare, C. J. (1996) Prediction of field use by Brent Geese; an aid to management. Crop Prot. 15: 259-268.

Morales, M. B., Suárez, F. and García de la Morena, E. L. (2006) Résponses des oiseaux de steppe aux différents niveaux de mise en culture et d'intensification du paysage agricole: analyse comparatice de leurs effects sur la densité de population et la sélection de l'habitat chez l'outarde canepetière Tetrax tetrax et l'outarde barbue Otis tarda. Rev. Écol. (Terre Vie) 61: 261-270.

Moreira, F., Morgado, R. and Arthur, S. (2004) Great Bustard Otis tarda habitat selection in relation to agricultural use in southern Portugal. Wildl. Biol. 10: 251-26o.

Nagy, S. (2009) International single species action plan for the Western Palearctic population of Great Bustard, Otis tarda tarda $<$ http://ec.europa.eu/environment/nature/ conservation/wildbirds/action_plans/docs/ otis_tarda.pdf $>$ (accessed 22 June 2013).

Osborne, P. E., Alonso, J. C. and Bryant, R. G. (200I) Modelling landscape-scale habitat use using GIS and remote sensing: a case study with Great Bustards. J. Appl. Ecol. 38: 458-471.
Pinto, M., Rocha, P. and Moreira, F. (2005) Long-term trends in Great Bustard (Otis tarda) populations in Portugal suggest concentration in single high quality area. Biol. Conserv. 124: 415-423.

Raab, R., Spakovszky, P., Julius, E., Schütz, C. and Schulze, C. H. (2011) Effects of power lines on flight behaviour of the WestPannonian Great Bustard Otis tarda population. Bird Conserv. Internatn. 21: 142-155.

Raab, R., Schütz, C., Spakovszky, P., Julius, E. and Schulze, C. H. (2012) Underground cabling and marking of power lines: conservation measures rapidly reducing mortality of West-Pannonian Great Bustards Otis tarda. Bird Conserv. Internatn. 22: 299-306.

Riddington, R., Hassall, M., Lane, S. J., Turner, P. A. and Walters, R. (1996) The impact of disturbance on the behaviour and energy budgets of Brent Geese Branta b. bernicla. Bird Study 43: 269-279.

Rocha, P., Marques, A. T. and Moreira, F. (2005) Seasonal variation in Great Bustard Otis tarda diet in South Portugal with a focus on the animal component. Ardeola 52: $371-376$.

Rocha, P., Morales, M. B. and Moreira, F. (2013) Nest site habitat selection and nesting performance of the Great Bustard Otis tarda in southern Portugal: implications for conservation. Bird Conserv. Internatn. 23: 323-336.

Sastre, P., Ponce, C., Palacín, C., Martín, C. A. and Alonso, J. C. (2009) Disturbances to Great Bustards (Otis tarda) in central Spain: human acitivities, bird responses and management implications. Eur. J. Wildl. Res. 55: 425-432.

StatSoft Inc. (2005) STATISTICA for Windows, 7.1. Tulsa, Oklahoma: StatSoft Inc.

Sterbetz, I. (1980) Investigations into the nutrition of the Great Bustard (Otis tarda L.) in the winter aspect of $1977 / 78$. Aquila 86: 93-100.

Streich, W. J., Litzbarski, H., Ludwig, B. and Ludwig, S. (2006) What triggers facultative winter migration of Great Bustard (Otis tarda) in Central Europe? Eur. J. Wildl. Res. 52: 48-53.

Tucker, G. M. (1992) Effects of agricultural practices on field use by invertebrate-feeding birds in winter. J. Appl. Ecol. 29: 779-790. 
RAINER RAAB, CLAUDIA SCHÜTZ, PÉTER SPAKOVSZKY, EIKE JULIUS

Technisches Büro für Biologie, Quadenstraße 13, A-2232 Deutsch-Wagram, Austria.

PÉTER SPAKOVSZKY

Institute of Wildlife Management and Vertebrate Zoology, University of West Hungary,

H-940o Sopron, Ady E. u. 5, Hungary.

CLAUDIA SCHÜTZ, CHRISTIAN H. SCHULZE*

Department of Botany and Biodiversity Research, University of Vienna, Rennweg 14, A-1030

Vienna, Austria.

*Author for correspondence; email: christian.schulze@univie.ac.at

Received 19 July 2013; revision accepted 30 September 2014; Published online 5 December 2014 